\title{
The Use of Ethnomathematics Learning Devices Based on Realistic Mathematics Education Models on Mathematics Literacy Mastery
}

\author{
Neza Agusdianita*, Victoria Karjiyati and Sufiyandi \\ Faculty of Teacher Training and Education, University of Bengkulu \\ "Corresponding author. Email: neza.agusdianita@gmail.com
}

\begin{abstract}
The main objective of this study was to develop learning ethnomathematics learning device based on Realistic Mathematics Education models on skill mastery in mathematics learning activities. The quasi-experimental technique was done by matching the pre-test and post-test control group. The study involves the State Elementary School (SDN) of Bengkulu city cluster 14 of class 4 as the population. Cluster random sampling is the technique applied to determine the sampling so that the study took class 4 at SDN 52 Bengkulu City as an experimental group and class 4 at SDN 24 as the control group. A test comprising of five questions in the form of description was the instrument used in this study. The test was given two times; before and after the learning activities in the experimental and control classes. The results of the t-test on students' post-test showed tcount $=3.19$, and ttable $=2.04$. Hence, tcount $>$ ttable indicated that there were differences in post-test results between the experimental and control class. It can be concluded that there is a significant influence on the use of ethnomathematics-based realistic mathematics models on literacy abilities in mathematics learning activities of the 4th grade at SDN XIV in Bengkulu city.
\end{abstract}

Keywords: Ethnomatematics, Realistic mathematics model, Mathematic mastery.

\section{INTRODUCTION}

Mathematics mastery can be learned by thinking or reasoning. In line with the opinion of Abidin [1] who stated that mathematics is useful for developing thinking skills and problem-solving in mathematics itself, other fields, and also in everyday life. It means that mathematics subject plays an important role in education and is closely related to the other sciences. Therefore, mathematics is given at the educational level from elementary school to university level. By studying mathematics, the problems in mathematics in daily life can be solved. The mathematics scores of students in Indonesia are relatively low.

According to Programme for International Student Assessment (PISA) in 2018 about mathematical literacy skills, consistently, PISA places Indonesian students in the lower ranks compared to the other countries. Based on PISA in 2018 , with a score of 3.79 . Indonesia placed at the 7 th rank out of 78 countries. Literacy of mathematics is the human's ability in formulating, using and interpreting mathematics in a variety of settings.
According to Mansur [2], Indonesia has a low mathematical literacy ability. The low ability of mathematical literacy in solving problems that exist in Indonesia must be addressed immediately. To overcome the low mathematical literacy of the students, the training by giving PISA questions on a regular basis becomes an alternative. It is expected that after their habit of working on these problems, students will get used to facing PISA problems and students' mathematical literacy abilities will improve greatly. In line with Johar [3], observers of mathematics education are expected to make innovations immediately in the learning process and the evaluation of mathematics in schools starting from the elementary school level which leads to mathematical literacy. The low mathematics of students in Indonesia is one of them because mathematics is an abstract of sciences. It exists only in human thought. These make children feel difficulty in understanding mathematics learning. While elementary school students are in the concrete operational stage (Piaget in Lestari and Yudhanegara, [4]. In other words, children were able to think 
systematically about concrete objects at the age of elementary school. This is in line with Brunner's theory that the learning process of elementary school students was at the enactive, iconic, and symbolic stages. Students will get experience or an event directly that relates to concrete objects in their surrounding environment.

Therefore, to help students understand mathematics and know-how to realize it in their daily activities, the learning can be done by emphasizing the use of situations that can be imagined by students themselves. The model that elevates the context of real-life as a source of learning is the Realistic Mathematics Education model (RME). Accordingly, Fathurrohman [5] the model of realistic mathematics can be interpreted as the learning activities that apply actual-world situations. The students will not easily forget about the notion of mathematics learning because the realistic mathematics Education model uses real situations and objects around in the learning activities. The results were the same as a research done by Karjiyati et al [6] entitled Development of Quantum Teaching Models in Mathematics Learning using Realistic Mathematics Education to Improve Learning Achievement, Creativity and Character of Elementary Students. The results of this study indicated that the RME model can improve the concept of understanding, creativity, and character development of elementary students.

In facilitating the students to understand the concepts of the learning cases, a source related to the students' environment is required. They can learn based on the culture in the close setting. Mathematics related to the culture around is so-called Ethnomathematics. This agrees with Gerdes in Dominikus [7] that ethnomathematics is a study of mathematics concerning culture. According to Sirate [8] the results of his research indicated that the ethnomathematics use was beneficial as the tools in motivating, stimulating, and overcoming difficulties of students in learning mathematics. This is because ethnomathematics is a part of students' daily lives which is an initial conception that has been owned by the local socio-cultural environment. Besides that, ethnomathematics gives a new nuance to mathematics learning.

This is supported by research Irawan and Kencanawaty [9]. Their research indicated that realistic mathematics learning based on ethnomathematics was one of the alternatives in classroom learning. The learning activities become more interactive so that the problems concerning daily activities can be studied by the students. Ethnomatematics'element becomes one of the teacher alternatives to provide learning that is linked to cultural elements with mathematics so that students are expected to know, love, and preserve culture.

One of the cultures of Bengkulu Province that is close to students is the Tabut Festival. In the construction of the Tabut building the requirements for mathematical content, it is geometrical material. According to the 2013 curriculum investigation, there was some basic competency of 4th-grade mathematics subjects that contain geometry material. The basic competition was KD 3.8 Analyzing the properties of the regular polygon and irregular polygon, then 4.8 identify a regular polygon and irregular polygon. In the KD above, students will learn mathematics by using the construction of the Tabut building. Geometry elements in the Tabut were found in the construction of the building.

By using Tabut's construction to find a concept, the students will explore and think creatively. Therefore the students can develop their mathematical literacy abilities. Mathematical literacy components to be investigated by the researchers are components of the process, contents, and contexts. In Fajriyah's research entitled "The Role of Ethnomatematics Related to Mathematical Concepts in Supporting Literacy" [10]. The results of this study indicated that ethnomathematics enables students to identify the concepts of mathematics as literacy according to their understanding of the socio-cultural background. Moreover, ethnomathematics offers the situation in which are greater and more fun encouragement for the students so that they can have more motivation to participate in the learning activities. It is hoped that the students' mathematics literacy can reach a better quality. The above explanation leads to the following objectives: 1) to produce mathematics learning divice with the RME model that are appropriate to be used in mathematics learning; 2) to produce effective learning tools to improve mathematical literacy skills; 3) to compare learning by using the RME model learning devices with conventional models learning devices in improving student literacy skills.

\section{METHOD}

This study was a research development. The study was done from February to March 2020 at SDN 52 Bengkulu City and SDN 24 Bengkulu City. The sample of this research was grade IV A students.

The population was the whole subject under research. The populations in this research were all grade IV elementary schools on the XIV group of Bengkulu city which consisted of SDN 24 Bengkulu City, SDN 52 Bengkulu City, SDN 45 Bengkulu City, and SDN 24 Bengkulu City.

The sampling technique was cluster random sampling. According to Winarni [11] this technique 
was used if a heterogeneous population is found because the sub-population of a group (cluster) has heterogeneous nature. In addition, this technique was used if a list of all population units is not obtained, so it was sufficient to list the clusters.

Samples were taken by random and carried out by drawing one of the elementary schools from the entire population. Four elementary schools cluster XIV with A accreditation in Bengkulu City were drawn to get one school that would become a testing ground, namely class IV SDN 45 Bengkulu City and class IV SDN 42 Bengkulu city. The researchers would draw in determining the control class and the experimental class. In conducting the study, the elementary school that would be used as an experimental group was class IV A SDN 52, and the control group was class IV A SDN 24 in Bengkulu City.

\section{RESULTS AND DISCUSSION}

The study indicates the results of development. At the initial stage, namely the stage of drafting mathematical learning tools namely the syllabus, lesson plans, worksheets, and the assessment instruments. The syllabus was developed based on Permendikbud Republic of Indonesia Number 60 of 2013 (Ministry of Education and Culture, 2013) concerning the basic framework and structure of curriculum (KI and $\mathrm{KD}$ ) mathematics material of polygon regular and polygon irregular terms) 2013 for elementary school and Permendikbud Republic of Indonesia Number 65 of 2013 (Ministry of Education and Culture, 2013) about process standards. In the syllabus, the learning activities developed are adapted to the syntax of the learning model that is used in this study namely the Realistic Mathematics Education (RME) model.

The lesson plans were developed referring to the prepared syllabus. The preparation of the lesson plans is also based on Permendikbud Republic of Indonesia Number 65 of 2013 (Ministry of Education and Culture 2013) about the standard process, and Permendikbud Republic of Indonesia Number 81A of 2013 and the Permendikbud Republic of Indonesia Number 103 of 2014 (Ministry of Education and Culture, 2014) regarding the implementation of the 2013 Curriculum. It was adjusted to the syntax of the RME model. The learning steps in this lesson plan are intended to direct the improvement of students' mathematical process skills and literacy abilities. It is by the research results that planning realistic mathematical learning activities by using the ethnomathematics theory enables students to define the notion of functions in mathematics effectively [12] [13].
The preparation of the worksheet (LKPD) was adjusted to the principles of the learning model (RME). LKPD was one of the teaching materials that serves to help students carry out learning. LKPD was arranged in a systematic, detailed, and clear way so that it could help students carry out learning. According to Widada [14], the contextual learning media application suitable to the students' needs can provide improvement in students' capabilities to achieve the notion and principle of mathematics. Accordingly, it can improve students' learning outcomes.

Contextual learning media can efficiently generate patterns that students can quickly compile conjectures. Besides, the students can accomplish the concepts and values that they are learning with the aid of more competent friends or teachers with vertical mathematical practices. It was found that more than 82 percent of junior high school students in Bengkulu City were able to properly achieve the principles and values of the application of learning media. The mathematical skill of students who learn ethnomathematics-oriented on YouTube media is also greater than that of students who do not learn ethnomathematics- oriented after mastering the initial abilities of the students [15].

The assessment of instrument was developed based on Permendikbud RI Number 66 the year 2013 related to assessment standards and Permendikbud RI Number 104 in 2014 related to the developed assessment also refers to the learning objectives that would be measured during the learning process and after learning. In this study, the assessment of instrument developed was a question of mathematical literacy skills.

After compiling a draft of the mathematics learning tool, it was continued to the validation process. The validation process in this study involved an expert lecturer and elementary's teacher. The following table shows the draft of validation results in RME learning device from elementary's teachers.

Table 1. The Validation of Learning Devices by Validators

\begin{tabular}{cllllll}
\hline No & \multicolumn{2}{c}{ INDICATORS / ASPECTES } & \multicolumn{3}{c}{ SCORE } \\
OBSERVED & $\mathbf{1}$ & $\mathbf{2}$ & $\mathbf{3}$ & $\mathbf{4}$ \\
\hline 1. & $\begin{array}{l}\text { Conformity between KI, KD, and } \\
\text { Indicators }\end{array}$ & & 3
\end{tabular}

2. Clarity of the formulation of learning objectives (does not lead to double interpretation)

3. Selection of learning material (conformity with the objectives and characteristics of the students) 
4. Organizing of learning materials (wrinkling, systematic, and time allocation)

5. Selection of learning sources / media (suitability and characteristics of the students)

6. Clarity of learning scenarios (learning steps in the initial, core and concluding stages)

7. Detailed learning scenarios (each step reflected in strategy / method and time allocation)

8. Appropriateness of assessment techniques with indicators / learning objectives

9. Complete instruments (questions, keys, scoring guidelines)

10 Integration and compatibility between components in the lesson plans

\section{Total score}

Based on table 1, it could be concluded that the learning model of the RME model was suitable in learning. Then the draft learning kit consisting of syllabus, lesson plans, worksheet (LKPD) and assessment instruments were included in the (good) category. In addition to assessing the draft learning trap, expert lecturers also provided some suggestions and comments for the improvement or revision of learning tools.

Table 2. The Result of the second pre-test samples

\begin{tabular}{ccc}
\hline Deskription & \multicolumn{2}{c}{ Pretest } \\
& Eksperiment & Control \\
\hline The lowest score & 8 & 2 \\
The highest score & 60 & 58 \\
Total & 868 & 734 \\
Average & 27,13 & 22,94 \\
Standard Deviation & 12,70 & 12,80 \\
Variant & 161,34 & 164 \\
Normality test & $-5,64$ & 9,95 \\
Homogeneity Test & $1.02<1,80=$ homogen \\
Hypothesis test & $1,32<2,04=$ Ha rejected \\
\hline
\end{tabular}

After the pre-test was carried out, both classes were given treatment, where in the experimental class with the use the RME model based on ethnomathematics.. The researchers used the Tabut as a culture of Bengkulu Province. The ethnomathematics-based RME model places more emphasis on the association between initial experience/knowledge and the environment around students about culture and the subjects taught so that learning became meaningful to students. Students were required to know the problems that occur in the environment and try to solve those problems. At the time of researching the experimental class and the teacher's control were required to be creative in presenting learning resources. In the experimental class, the teacher presented a miniature Tabut building while in the control class used the EEC model. In the control class, the teacher presented Figures of getting up flat. By using real learning resources, students were more active and enthusiastic. The results showed that through learning with the ethnomathematics approach students could carry out the process of abstraction, idealization, and generalization about geometric objects. Students can do interiorization and encapsulation in the form of geometric concepts and principles. It is done through specialization and generalization [16] [17].

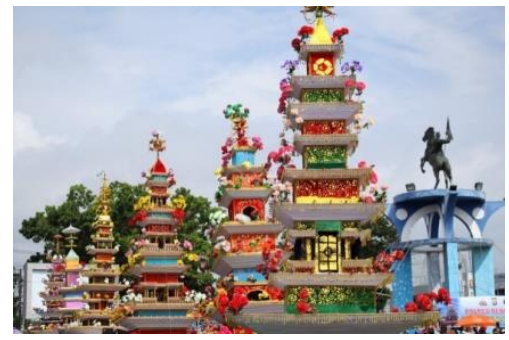

Figure 1: Example of Tabut

The figure above was a sample of the Tabut in Bengkulu Province. There was an element of geometry in the building of the Tabut. It shows triangles, rectangles, and squares. Therefore, the Tabut could be used as a source of learning based on ethnomathematics because it contained cultural and mathematical elements in it. This was following the opinion of Adi et al [18] who said that teachers can create creativity by means of the media-assisted RME model to make the learning process more meaningful.

In the experimental class, the first step was to understand contextual problems. Learning begins with the teacher inviting students to observe the surrounding environment first, namely observing the classroom. After that students and teachers asked questions about the objects in the form of flat shapes. Then the teacher invited students to observe the tabut in front of the class. But the Tabut's miniature did not yet represent all the material of flat build, therefore the teacher provided another tabut of a 
miniature that has been made to represent all of the materials flat build. Utilization of the miniature of the tabut fosters motivation of learning, students were very enthusiastic and ask about learning material so that their interest in learning highly. RME learning made students feel happy, comfortable, and enthusiastic in learning, students also always remember the mathematical concepts obtained all because the students were looking for themselves. When students understand contextual problems, according to Chisara [19] through the RME model approach students could find out the relationship between mathematics and everyday life. Representation of activities in the step of understanding contextual problems could be seen in Figure 2.

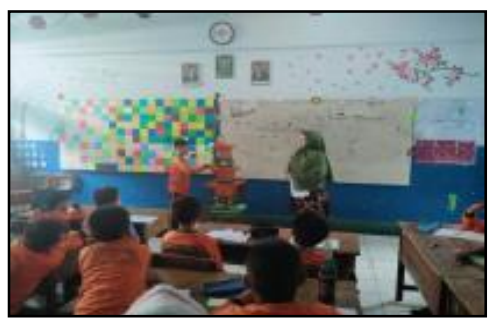

Figure 2. Step-1 of RME Model

The second step was solving contextual problems. At this stage, students were divided into groups and discuss to work on LKPD. The teacher asked students to look for geometrical structures found in miniature tabut buildings that had been shared by each group. The teacher asked students to analyze the elements of a geometric and irregular polygon in the miniature of the tabut. This made students feel challenged and interested in identifying problems. Students shared their assignments such as those who write the results of discussions, some who observe the miniature of the tabut, some dictate and some report the results of the discussion to the class. They worked faster because they used concrete objects. The teacher went around giving the opportunity to students to ask if there was something not yet understood. Similarly, Shoimin [20] stated that guidance becomes an important principle of Realistic Mathematics Learning when students discover mathematical principles, concepts, or formulas and students experience difficulties, the teacher will guide them. The activity representation in this step of solving contextual problems is shown in Figure 3.

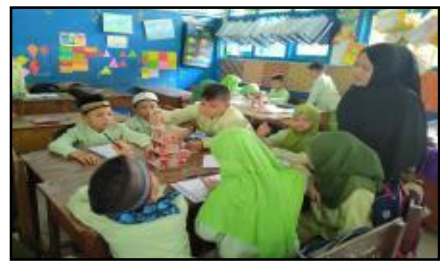

Figure 3. Step 2 of RME model.
The third step was comparing and discussing answers. At this stage, each group reported the results of the discussion in front of the class by bringing a miniature tabut as the medium to assist in reporting the results of the discussion. Students would read the results of the discussion systematically using a miniature tabut. After that, the teacher asked answers to the other groups about the results of the group discussion going forward to the class. After questions and asks, the teacher gave reinforcement about the material in terms of polygon regularity and polygon irregularity. Similarly, Syamsyudin noted that more students are actively interacting with other students or teachers, and it is better to convert information on story problems or problems into a mathematical model or in a mathematical expression. The activity representation in the steps of comparing and discussing answers is shown in Figure 4.

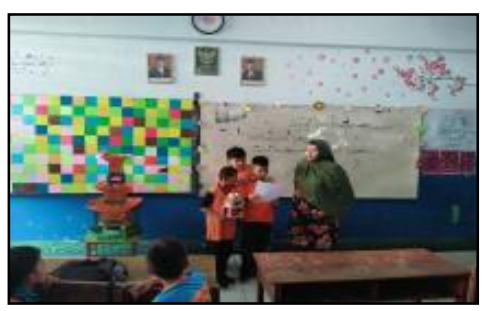

Figure 4. Step-3 of RME Model.

The fourth step was to conclude. At this stage, both students and teachers concluded the subject matter that has been learned. The teacher provided opportunities for students to make conclusions about the material that they had learned. After that, the teacher gave the stabilization of the material for students to write the conclusions in their respective notebooks. According to Heryan and Zamzali, ethnomathematics-based learning is significantly better than conventional learning to improve students' conceptual understanding abilities. But the material in terms of polygon regularity and material in terms of polygon irregularity is less suitable for literacy because of the high demands of literacy, whereas in terms of polygon matter only deals with the properties of the building.

The influence of the ethnomathematics model on students' mathematical literacy ability was because in learning mathematics using the ethnomathematics RME model students were actively involved and students discovered directly and explore their knowledge, learning resources were presented directly in the classroom so students were able to build literary habits. Based on previous research, Fahmi et al [21] stated that RME activity is a learning type designed to improve mathematics literacy skills. For students whose instruction is a scientific approach, the ability to grasp the mathematical principles of students who are taught using the associated mathematics learning paradigm is better than for students who are 
conventionally taught. It applies a similar effect on students' learning activities [22]. Through learning that is close to students' minds and the ethnomathematics approach can improve problemsolving skills [23], mathematical communication [24], and overcome mathematical difficulties [25] [26] Also, it was to improved mathematical abilities.

In the control class that used the EEC model (exploration, elaboration, confirmation). At this stage, the teacher gave an explanation of geometrical shapes by using images. The media used in the control class was only in the form of flat shapes. Learning resources presented were only based on learning books. The teacher appointed one of the students forward to show the geometry in the Figure. When the teacher asked who wants to answer the question, students tended to be passive and afraid to advance. Different from the conditions in the experimental class.

The second step was elaboration. In this step, students were divided into heterogeneous groups to discussed student discussion sheets. Students discussed and worked on the questions according to the Figures available at LKPD. During the group discussion process, students took longer to work on the problems than in the experimental class. Some students write the results of answers, some students dictate the answers and tones of students who measure images. The teacher went around to see the work of students.

The final step was confirmation. In this step, each group reported the results of the discussion in front of the class by bringing the LKPD results. Students read the results of the discussion systematically. After that, the teacher asked answers to the other groups about the results of the group discussion going forward to the class. Both students and teachers concluded the subject matter that has been learned. The teacher provided opportunities for students to made conclusions about the material that they had learned. After that, the teacher gave the stabilization of the material for students to write the conclusions in their respective notebooks.

Table 3. The result of the second post-test

\begin{tabular}{|c|c|c|}
\hline \multirow{2}{*}{ Deskription } & \multicolumn{2}{|c|}{ Postest } \\
\cline { 2 - 3 } & Eksperiment & Control \\
\hline The lowest score & 36 & 18 \\
\hline The highest score & 82 & 78 \\
\hline Total & 1903 & 1542 \\
\hline Average & 59,47 & 48,19 \\
\hline Standard Deviation & 12,57 & 15,59 \\
\hline Variant & 158 & 243,06 \\
\hline Normality test & 6,15 & 7,74 \\
\hline Homogeneity Test & $1,54<1,80=$ homogen \\
\hline Hypothesis test & $3,19<2,04=$ Ha Accepted \\
\hline
\end{tabular}

From the table above, it can be concluded that learning tools that use the RME model were better for increasing the literacy ability of students than those using conventional models. The results, provide reinforcement of previous research. Local culture is the starting point for learning mathematics. This is to make it easier for students to recognize the concepts needed, making it easier for students to establish ties between concepts. Besides, It will make the ideals of reduction, substitution, and combination simpler for students to achieve. The result of this study is that studying ethnomathematics about the community of Bengkulu fishermen can solve the difficulties of students knowing the linear equation system. The understanding of the number of students taught with associated learning in mathematics is better than that taught with traditional learning models. The overall score of the willingness of students to grasp the notion of numbers in students who received local culturebased material was greater than students who received local culture-based material (ethnomathematics) [27]. There are differences in mathematical abilities for students who are taught with realistic mathematics approaches compared with students taught with traditional learning. Also, the mathematical skills of ethnomathematical oriented students were better than those who were non-ethnomathematical oriented [26]. This gives confidence that realistic mathematics learning and ethnomathematics approaches have a positive influence on students' mathematical abilities in elementary schools.

\section{CONCLUSION}

The following conclusions are drawn based on the explanation and discussion of this study: 1) mathematics learning devices with the RME model are suitable in mathematics learning, 2) RME model is effective in improving mathematical literacy skills, 3) learning by using the RME model learning tools is better in improving students' mathematical literacy skills than conventional model learning devices in improving student literacy skills.

\section{ACKNOWLEDGMENT}

We would like to thank the research and community service institute, Bengkulu University. Thank you for the support of funding and facilities.

\section{REFERENCES}

[1] Abidin, et al., Pembelajaran Literasi:Strategi Meningkatkan Kemampuan Literasi Matematika, Sains, Membaca, dan Menulis, Jakarta: Bumi Aksara, 2018.

[2] Mansur, N, Melatih Literasi Matematika Siswa dengan Soal PISA, no.1, 2018. pp:140-144 
[3] Johar, R., Domain Soal PISA untuk Literasi Matematika, Jurnal Peluang, vol. 1, no. 1, 2012. pp. 30-41

[4] Lestari, K.E, \& Yudhanegara, MR., Penelitian Pendidikan Matematika. Karawang: PT.Refika Aditama, 2015.

[5] Fathurrohman, M., Model-model Pembelajaran Inovatif. Yogyakarta:Ar-Ruzz Media, 2015.

[6] Karjiyati, et al., Pengembangan Model Quantum Teaching dalam Pembelajaran Matematika Menggunakan Realistic Mathematics Education untuk Meningkatkan Prestasi Belajar, Kreativitas, dan Karakter Siswa SD. Vol. 7 No. 2. 2014. pp. 228-234.

[7] Dominikus,WS., Etnomatematika Adonara. Malang:Media Nusa Creative, 2018.

[8] Sirate, FS., Implementasi Etnomatematika Dalam Pembelajaran Matematika Pada Jenjang Pendidikan Sekolah Dasar, Jurnal Pendidikan, vol. 15 , no. 1, 2012. pp. 41-54.

[9] Irawan, A and Kencanawaty, G., Implementasi Pembelajaran Matematika Realistik Berbasis Etnomatematika. Vol. 1 No. 2, 2017. pp. 74-81.

[10] Fajriyah, E., Peran Etnomatematika Terkait Konsep Matematika dalam Mendukung Literasi, No.1, 2018. pp. 114-119.

[11] Winarni, E.W., Penelitian Kuantitatif Kualitatif. Jakarta:Bumi Aksara, 2018.

[12] Herawaty, Dewi, Widada, W., Adhitya, A., Sari, R. D. W., \& Novianita, L. Students ' ability to simplify the concept of function through realistic mathematics learning with the ethnomathematics approach. IOP Conf. Series: Journal of Physics: Conf. Series 1470 (2020) 012031 Doi:10.1088/1742$6596 / 1470 / 1 / 012031,1470,2020$. pp. 1-8. https://doi.org/10.1088/1742$6596 / 1470 / 1 / 012031$

[13] Widada, Wahyu, Herawaty, D., Beka, Y., Sari, R. M., \& Riyani, R. (2020). The mathematization process of students to understand the concept of vectors through learning realistic mathematics and ethnomathematics. IOP Conf. Series: Journal of Physics: Conf. Series 1470 (2020) 012071 Doi:10.1088/1742-6596/1470/1/012071, 1470, $1-10$. 6596/1470/1/012071

[14] Widada, Wahyu, Proses Pencapaian Konsep Matematika dengan Memanfaatkan Media Pembelajaran Kontekstual. Jurnal Penelitian Pendidikan Matematika Dan Sains, 22(1),
2015. pp.31-44. Retrieved from https://id.wikipedia.org/wiki/Pembelajaran

[15] Nugroho, K. U. Z., Widada, W., \& Herawaty, D. The Ability to Solve Mathematical Problems through Youtube Based Ethnomathematics Learning. International Journal of Scientific \& Technology Research, 8(10), 2019. pp. 1232-1237

[16] Widada, Wahyu, Herawaty, D., Ma'rifah, N., \& Yunita, D. Characteristics of Students Thinking in Understanding Geometry in Learning Ethnomathematics. International Journal of Scientific \& Technology Research, 8(11), 2019. pp. 3496-3503.

[17] Widada, Wahyu, Herawaty, D., Andriyani, D. S., Marantika, R., \& Yanti, I. D. The thinking process of students in understanding the concept of graphs during ethnomathematics learning. IOP Conf. Series: Journal of Physics: Conf. Series $1470 \quad$ (2020) 012072 Doi:10.1088/1742-6596/1470/1/012072, 1470 , 2020. pp. 1-8. https://doi.org/10.1088/17426596/1470/1/012072

[18] Adi, et al., Pengaruh Model RME Berbantuan Media Semi Konkret Terhadap Hasil Belajar Matematika Siswa Kelas V SD Gugus 8 Kecamatan Gianyar,Kabupaten Gianyar Tahun Ajaran 2013/2014, Vol. 2 No.1. 2014.

[19] Chisara, et al, Implementasi Pendekatan Realistic Mathematics Education (RME) dalam Pembelajaran Matematika, 2018. pp. 65-72

[20] Shoimin, A. 69 Model Pembelajaran Inovatif dalam Kurikulum 2013.Yogyakarta: ARRUZZ Media, 2017.

[21] Fahmy, et al., Kemampuan Literasi Matematika dan Kemandirian Belajar Siswa Pada Model Pembelajaran (RME) Berbantuan Geogebra, 2018. pp: 559-567

[22] Widada, W. et al. The improvement of trigonometry ability through connected mathematics learning models and scientific approaches The improvement of trigonometry ability through connected mathematics learning models and scientific approaches. Journal of Physics: Conference Series, 1318(012078), 2019. pp. 1-6. https://doi.org/10.1088/17426596/1318/1/012078

[23] Widada, W, Herawaty, D., Mundana, P., Agustina, Putri, F. R., \& Anggoro, A. F. D. The REACT strategy and discovery learning to improve mathematical problem solving ability The REACT strategy and discovery learning to improve mathematical problem solving ability. 
Journal of Physics: Conference Series PAPER, 1318(012081), 2019. pp. 1-5. https://doi.org/10.1088/1742$6596 / 1318 / 1 / 012081$

[24] Herawaty, D, Gusri, S. A., Saputra, R., Liana, E., \& Aliza, F. The mathematics communication of students in learning based on ethnomathematics Rejang Lebong The mathematics communication of students in learning based on ethnomathematics Rejang Lebong. Journal of Physics: Conference Series PAPER, 1318(012074), 2019, pp. 1-8. https://doi.org/10.1088/1742$6596 / 1318 / 1 / 012074$

[25] Widada, Wahyu, Herawaty, D., Rahman, M. H., Yustika, D., \& Elsa, P. Overcoming the difficulty of understanding systems of linear equations through learning ethnomathematics. IOP Conf. Series: Journal of Physics: Conf. Series 1470 (2020) 012074 Doi:10.1088/17426596/1470/1/012074, 1470, 2020, pp. 1-14. https://doi.org/10.1088/1742-

$6596 / 1470 / 1 / 012074$

[26] Andriani, D., Widada, W., Herawaty, D., Ardy, H., Nugroho, K. U. Z., Ma'rifah, N., ... Anggoro, A. F. D. Understanding the number concepts through learning Connected Mathematics (CM): A local cultural approach. Universal Journal of Educational Research, 8(3), 2020. pp. 1055-1061 https://doi.org/10.13189/ujer.2020.080340

[27] Widada, W, Nugroho, K. U. Z., Sari, W. P., \& Pambudi, G. A. The ability of mathematical representation through realistic mathematics learning based on ethnomathematics The ability of mathematical representation through realistic mathematics learning based on ethnomathematics. Journal of Physics: Conference Series, 1318(012073), 2019. pp. 18. https://doi.org/10.1088/1742- 